\title{
South-South cooperation: Brazilian soy diplomacy looking East?
}

\author{
Jeroen Warner ${ }^{1}$
}

Received: 3 September 2015 / Accepted: 21 September 2015 /Published online: 25 November 2015

(C) The Author(s) 2015. This article is published with open access at Springerlink.com

\begin{abstract}
Ever since the food price crisis of 2007/8, concerns about global food supply interruptions have mounted. However, while exports from Brazil, the world's leading soy exporter, are currently under threat, this is not due to geopolitical concerns, but due to resource mismanagement. As a consequence, the country with the most water availability per person is mired in an enduring water crisis, impacting on its major water transport routes. Brazil's development model is based on an oligopolistic public-private, primary-sector conglomerate, fueled by the federal investment bank, BNDES. This article argues that Brazil has embarked on an unsustainable model of development and is exporting that model as part of its 'South-South Cooperation' (SSC) drive. Like the other BRICS, Brazil is using SSC to present itself as non-ideological and antiimperialist but, in fact, uses the cooperation strategy for diplomatic and self-interested economic purposes. The Middle East is specifically targeted as a region with 'complementary' interests: rich in fossil fuels, poor in land and water and plenty of petrodollars to buy food security. The current water crisis shows limits to this complementarity, in the process undermining the assumption that 'virtualwater exports' promoted by competitive specialization are salutary to the global water balance.
\end{abstract}

Keywords Water availability · Virtual water · Oligopoly · Soybean

Jeroen Warner

jeroenwarner@gmail.com

1 Social Sciences Group, Wageningen University, Wageningen, Netherlands

\section{Introduction}

Global agro trade is expanding, and Brazil is benefiting. The upsurge in global soya exports from the 'soya republic' of South America's Southern Cone is booming - at the cost of US and Canadian soy trade ${ }^{1}$ — now making Brazil the world's biggest soya exporter. Brazil's seemingly limitless resource wealth has incited an export drive to supply food and fodder to resource-poor countries such as the Gulf states (soy exports to the region were at a record level in 2014), ${ }^{2}$ and the country is expanding its efforts into the African subcontinent under the heading of South-South cooperation in order to repeat its apparent success. This globalising tendency has been referred to as the globalisation of virtual water neo-liberalism (Boelens and Vos 2012).

More trade, however, also means greater dependency. Price spikes and land grabs have created an added sense of instability and exploration of the consequences of interrupted global supply chains, in which political shock scenarios play a prominent role (e.g., PBL 2011 [the Dutch Environmental Planning Agency]. How realistic are geopolitical fears of global supply interruption, such as a Brazilian export ban impacting on the Middle East?

\footnotetext{
1 'South America's Southern Cone, where soy is the "the monoculture 'starlet' of the agro-export model", produces 57 percent of global soybean exports' (Oliveira and Schneider 2014)

${ }^{2}$ Alexandre Rocha, Brazil runs a US\$ 2 billion surplus in trade with Arabs. Brazil-Arab News Agency. 14 January 2015. www2.anba.com. br/noticia/21866479/global-trade/brazil-runs-us-2-billion-surplus-intrade-with-arabs/

Saudi Arabia raising soybean and corn imports from Brazil. Arab News 8 March 2015. http://www.arabnews.com/saudi-arabia-raisingsoybean-and-corn-imports-brazil

Online: http://www.arabnews.com/saudi-arabia-raising-soybeanand-corn-imports-brazil; See also McGinley 2012
} 
This article will argue that Brazil's soy exports are indeed under stress, but not for geopolitical reasons. Brazil proves to be a bewildering case of a 'resource curse' economy shooting itself in the foot by failing to address some root causes. Otherwise, how does a supposedly resource rich country still manage to be in a water crisis?

A different picture is presented in this article. After introducing geopolitical security concerns related to the global agri-food system, it examines South-South cooperation in the light of Brazil's geopolitical strategies. It then relates current-day food politics with the Green Revolution 2.0 now taking place and the post-2008 obsession with the waterenergy-food (WEF) nexus, which suggests the substitution of water-for-energy with water-for-food bring joint security benefits. ${ }^{3}$ This is predicated on the continued transfer of virtual water from water-rich to water-poor regions, presupposing an unlimited supply and requiring a political rationality not ostensibly in evidence in Brazil.

\section{The security pitfalls of global interdependence}

Tony Allan's virtual water thesis (Allan 2001) sees green (root-zone) water from water-rich temperate countries exported to the water-poor semi-arid regions, notably the Middle East, as a silent global redistribution mechanism through the global market and food aid. This has fostered temperate-zone countries to seek markets abroad, as the domestic market is too small. Moreover, in the case of Brazil, technological breakthroughs also enabled tropical zone production to expand and for the country to become the first tropical food giant after a top-five of temperate-zone producers (United States, Canada, Australia, Argentina and the European Union).

The idea is that global agricultural trade evens out the uneven global distribution in water endowments and in so doing prevents water resource conflict with minimum fuss (Allan 2001). In the past decades, the World Bank and FAO have recommended the Middle East to step up its food imports in light of its poor water and arable land endowment (Harrigan 2014).

Relying on trade interdependence however proved problematic when global food prices exploded in 2007-2008. The 2007/8 food price spike has led to concerns about security implications of shocks in the agrifood trade, a possible repetition of the early 1970s, when the prices of rice, wheat, maize, and soy beans also went through the roof after geopolitical upheavals in response to the first oil shock, among other

\footnotetext{
${ }^{3}$ Some would add phosphorus and rare earths to the mix, arriving at a resource nexus which 'originates in the interconnections between different resources, in other words, the requirement that one (or more) resource is used as an input to produce another resource' (PBL 2011).
}

factors. The price rise and subsequent lack of local access resulted in food riots in more than 20 countries (Jafri 2008), leading several analysts to relate the so-called Arab Spring to continued food insecurity (HCSS 2013; Harrigan 2014). In an uncertain context, resource nationalism or conflict can cause shocks to trade, hurting imports and/or exports. In such cases, the response time of a heavily import-dependent economy may vary, depending on its adaptive resilience (HCSS 2013).

Food importers started to worry about global supply chain interruptions (HCSS 2013; PBL 2011; Bleischwitz et al. 2012; Bindraban et al. 2009). This is important for resource-poor, agro-importing countries. While the causal link between food scarcity and revolution is unclear, the availability, affordability and accessibility of nourishing food is important to the implicit social contract in authoritarian-paternalistic systems in the Middle East. Most Middle East states are still highly foodsecure in terms of calories; yet this security is under pressure (Woertz 2011, 2013) and even more so with currently volatile oil prices, which affect their ability to pay for food imports. The region is therefore vulnerable to sudden interruptions in the supply chain. Reduction of water use and introduction of greenhouses cannot eliminate this risk.

Apart from export restrictions, HCSS (2013) also see vertical concentration of the food industry as a political risk, increasing the effective control of the sector and in so doing the potential for sharp changes in strategy. This seems a realistic assessment at a time in which state capitalism, while never really absent from the scene, has become much more prominent with the rise of the BRICS (Brazil, Russia, India, China, and South Africa) on the global scene.

The year 2008 saw export restrictions from Russia, Argentina and Vietnam (see also Burger et al. 2010a, b). Brazil asserted its sovereignty by seeking to restrict foreign land ownership. Meanwhile, Foreign Direct Investment (FDI) was stepped up through investor companies more often than not (partially or wholly) state-owned or controlled. In 2012 the BRICS even explicitly stressed the pivotal economic role of State-Owned Companies (SOCs).

Having amassed an apparent surfeit of foreign reserves and looking for investment opportunities, the agricultural drive is also a strong impetus for Brazil to look East across the Atlantic. Successful overseas agricultural export drives make domestic exploitation ventures step up a gear. These are run by companies that are more often than not under the tutelage of the state. ${ }^{4}$ The question is what kind of development this aids: a Rostowian transition/'take-off' or a (re)prioritization of economies? The question is addressed in the following

\footnotetext{
${ }^{4}$ In Angola, for example, Dos Santos has been President for 33 year, and has had a long-term relations with Btazoloam TNC Odebrecht. Brazilian companies present in Africa, especially in Angola are :- Odebrecht construction, OAS, Camargo Correa, and Andrade Gutierrez.
} 
discussion in the context of the rise of the BRICS economies as 'middle global powers' and South-South cooperation.

\section{The new middle powers: reinventing state capitalism in a multipolar age}

Since 1989, not only global East and West, but also North and South demarcations have become ever more blurred. Regional powers now seek global reach and have leadership (Sadik 2013) whether it is the BRICS in agriculture and mining or the Arab Gulf states in energy. However contradictory, Sadik argues, they are all 'occupying prominent positions in the global supply chain' and production networks, and have all built up enormous reserves, which flow to financial centres. An example is what Hanieh (2011) has dubbed the Khaliji ('Gulf') capital of the Arab Gulf states, who are not only key players in fossil fuel production but also financial movers and shakers from their petrodollar surpluses and increasingly through Sovereign Wealth Funds and private equity firms as well as wielding geopolitical influence outside their orbits.

In so doing, they challenge global arrangements that are taken for granted. Yet, counterhegemonic as the ascent of the BRICS may look, they seem not so much bent on toppling the global hegemon, as on transforming the international regime - the 'international trade/finance architecture' and structures shaping what may be called the governance of globalisation. This state-centric term is chosen in preference to the liberal-institutional fixation on global governance - as the latter would threaten state sovereignty (Burger et al. 2010a, b) ${ }^{5}$. Boundaries and sovereignty are still very much in evidence, all the more so since the food price explosion of 2007/8.

The rise of the middle powers, regional hegemons and global contenders, is an underappreciated corollary to tales of relentless globalisation. The new regional hegemons need to control their hinterland, but may hardly enjoy any trust by or legitimacy from their neighbours, and even run into land conflicts. For example, Brazil needs to deal with scuffles between Brazilian settlers in Paraguay (brasiguaios) and stateto-state conflicts over energy with Bolivia. On the plus side, economic and political success is a strong attractor, a source of soft power in its own right (Nye 1990). Brazil takes the lead in trade bloc (Mercosur), infrastructural integration and transboundary projects such as the Rio Madeira canal (hidrovia) to Peru facilitating soy exports there.

The new powers do not have a strong ideological message, but are content to work through existing institutions, often by reinforcing power structures (Carmody 2011). There is merit in the observation that without neoliberal policies forcing the

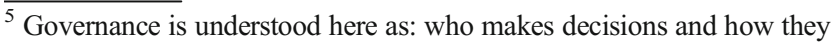
are made (Bakker 2007)
}

door open in the past, many current investors would not have been so successful. Yet Harvey (2009) has argued that those which survived best have resisted further open doors. Brazil and China profess wariness of neo-liberalism and promote maybe not so much an alternative to, but a 'rebalancing' of imposed Washington Consensus reforms.

But unlike radical and liberal accounts, the state did not bounce back in this new arena, in favour of an unfettered market, in which boundaries no longer matter. Instead, activist development states assert their sovereignty and agency domestically and internationally. Even the Economist has been referring to the rise of 'state monopoly capitalism' (Lassance 2012; Kuntz 2014). The world order is now decidedly looking less liberal-internationalist than was predicted after the fall of the Berlin Wall a quarter century ago (Gray 2014). The activist state remains alive and kicking.

\section{South-South cooperation}

In the past decade or so, the above-mentioned disparate multilateralism assumed an attractive package in South-South cooperation, an attractor deemed so important that the UN has dedicated a day to it (12 September).

While Russia defies Europe in Ukraine and Syria and Chinese keep sabre-rattling on the Daikyu/Senkaku islands, generally the BRICS have carved out their global position through exercising soft power, rather than openly challenging the United States and its echoes of the Truman Doctrine. If with different vernacular, all BRICS voice an explicitly anti-neoliberal rhetoric, promoting a noncolonial development model reminiscent of the NonAligned Movement of the 1950s and the New International Economic Order of the 1970s (Sommerville et al. 2014) though clearly the international financial and economic architecture of the day was more propitious under the Bretton Woods system. This history resonates in Brazil's campaign for global inclusion and distributive justice and political and economic emancipation from the early $21 \mathrm{st}$ century. Brazil's dominance in its South-South cooperation is smaller, not targeting peasants, leaving implementation to African partners, and practising non-interference in domestic issues, not critical of domestic inequalities, only of global inequalities. As such, Cesarino (2012) claims present-day Brazil displays a refreshing restraint from labelling the Other as backward, underdeveloped, different.

The BRICS likewise seem deeply disinterested in America's wars in the Middle East, and Brazil's diplomatic forays into the Middle East are greatly helped by not ostentatiously being about fossil fuels or national-security issues. Brazil is considered to be very resource-rich and has successfully transformed its energy economy, reducing dependency 
on fossils by converting to hydropower and biofuels. Thus, access to resources is not the primary driver.

Rather, Brazil claims that it merely seeks to copy its domestic successes abroad and does so by emphasising transferability of achievements, despite well-known warnings against copy-paste. An example is Brazil's social security (safety-net) system, Bolsa Familia (Conditional Cash) now supported by the World Bank and Britain's DFID. Following a planningdominated history, Brazil, like many other countries liberalized, rescaled and decentralised its agricultural production in 1997. Yet under the PT (Partido dos Trabalhadores, Workers' Party)-led coalition government, Brazil displays many of the trappings of a neo-Fordist development state, if in a decidedly different global constellation, and has impressively managed to reduce its own poverty. The expectation is that it will behave accordingly in its development projects abroad. Brazil prefers to talk of 'horizontality, exchanging knowledge and sharing experiences, cooperation', a discourse predicated on the idea that 'African countries have much to learn from Brazil's store of successful experiences in sectors such as tropical agriculture' (Cesarino 2012).

The prevailing discourse of South-South cooperation has sparked debates about its merits. Various authors (Table 1) have identified a divergence in the assessment of the nature of South-South cooperation, whose discourse promotes 'horizontal' South-South cooperation as an alternative to 'vertical' North-south development. Does this bring equal partnership, symmetric relations built on 'soft power' (Amanor 2013) or asymmetry and domination-'involvement in the international market in a subordinate position that "serves the globalisation" of transnational capitalism" (Prashad 2013)? A neo-dependencia ${ }^{6}$ school on the other hand claims BRICS practices are not that different from their predecessors, and wonders how much 'cooperation' there is in South-South cooperation. In the middle is a 'realist' (Realpolitik) approach that sees neither good nor evil in state behaviour (See Table 1). Employing different labels, each publication listed in Table 1 comes up with a variety of what I grouped as an 'optimist-idealist', a 'Realist' and a 'negative-catastrophist' interpretation of South-South cooperation.

This last tradition of explaining underdevelopment, dependencia, was developed by Latin American structural economists such as Andre Gunder Frank and Raúl Prebisch at CEPAL/ECLA. Dependencia evolved into World-systems

\footnotetext{
${ }^{6}$ Dependency or dependencia theory arose in the 1970 s in contradistinction to modernisation theory, and claims that "resources flow from a "periphery" of poor and underdeveloped states to a "core" of wealthy states, enriching the latter at the expense of the former. It is a central contention of dependency theory that poor states are impoverished and rich ones enriched by the way poor states are integrated into the "world system." (Wikipedia). Key figures are Andre Gunder Frank and Osvaldo Sunkel.
}

theory, which helps us understand global relations as economic exploitation, whether of people or resources (Wallerstein 1974). The neo-Marxian world-systems tradition sees foreign direct investment as neo-colonial competition between imperialist powers extracting resources for their reproduction. World-systems analysts identify a hierarchically ordered (and multi-level) global core, semi-peripheral and peripheral groupings. The system's economic core extracts resources from the periphery, often aided by a venal'comprador bourgeoisie' in the periphery, selling out natural resources to foreign investors for private gain. Middle powers (subimperialists) act as transmission belts and sources of innovation between core and periphery.

The Brazilian social scientist Ruy Marini (1972) claimed Brazil's dictatorship enabled it to become a subimperialist, its state capitalism founded on monopoly industries notably in construction, co-opting national and international capital, notably servicing American interests. Marini argued that local capitalism in Brazil was strong enough to maintain a relationship of cooperative competition with the global hegemon. Following in his footsteps, Zibechi (2014) sees Brazil under the leadership of the Workers' Party (PT) loosening ties with the US and embracing South-South Alliances while still subservient to international capital. Zibechi argues that an intersectorial coalition of unionists, bureaucrats and large company owners controls the state, industry and key social spheres with the lineage of Portuguese colonial structures.

The view that 'Southern' elites largely follow 'core' ideas and interests has remained influential. We do not fully need to go with this view of the Brazilian state as a handmaiden of 'Northern' interests to see ample evidence of public-private collusion. The next section goes into this constellation governing the food sector.

\section{'Collaborative capitalism'?}

'Neoliberalism' may be a misnomer for the hegemonic trend in this arena; instead we may well find ourselves in an era of 'collaborative capitalism' (Greider 1997). Developments in the food sector both reaffirm and contradict a supposed neoliberal order (McMichael 2009).

Shocks and crises are often held to herald a new era, but upon closer scrutiny, they only accelerate emerging patterns (Kelman 2006). Since the food price explosion of 2007/2008, resource mercantilism has gained strength (McMichael 2009; Koning and Mol 2009). The food price rise dramatically accelerated the pace of protectionism at home and resource imperialism abroad.

It may be recalled that at the outset of this contribution, vertical integration was identified as a security risk. In the past decade, Latin America has seen a strong 'downstream 
Table 1 Comparison of classifications of discourses on South-South Cooperation

\begin{tabular}{|c|c|c|c|}
\hline Author(s) & Optimist-idealist discourse & Realist discourse & Pessimist-catastrophist discourse \\
\hline Vieira (2011) & $\begin{array}{l}\text { International solidarity, } \\
\text { anti-colonialism and } \\
\text { decrease of dependence }\end{array}$ & Not mentioned & $\begin{array}{l}\text { 'Soft imperialism', business diplomacy, } \\
\text { neocolonialism. }\end{array}$ \\
\hline $\begin{array}{l}\text { Nogueira and Ollinaho } \\
\text { (2013) }\end{array}$ & $\begin{array}{l}\text { Ethical, cultural utilitarian } \\
\text { strategy }\end{array}$ & $\begin{array}{l}\text { South-South Cooperation } \\
\text { as one instrument to } \\
\text { defend development } \\
\text { interests on a global scale }\end{array}$ & $\begin{array}{l}\text { 'Subimperialism', seeks sphere of } \\
\text { influence within existing hegemony }\end{array}$ \\
\hline Agbo (2008) & $\begin{array}{l}\text { Mutual benefits, countries } \\
\text { with a common past and } \\
\text { similar problems of } \\
\text { development should assist } \\
\text { each other }\end{array}$ & $\begin{array}{l}\text { Southern economies seek } \\
\text { imperialism for their own } \\
\text { sake ('Protoimperialism') }\end{array}$ & $\begin{array}{l}\text { Rising Southern economies as agents of } \\
\text { northern economies, transmission belts } \\
\text { between core and periphery (Subimperialism) }\end{array}$ \\
\hline
\end{tabular}

concentration' in the food chain coupled with economic state activism. 'Much of South-South cooperation... has been provided by state institutions and actors, and in Brazil this prevalence is nearly absolute' (Cesarino 2012). In fairness, not all major players in BRICS are state-controlled, and transnational companies (TNCs) continue to dominate the global market. Here too however, liberal doctrine falls flat as transactions become based on industrial relationships rather than on open markets-a phenomenon the journalist William Greider has aptly labelled 'cooperative capitalism' - modalities may change, but structural inequalities are perpetuated (Greider 1997).

While Brazil has manifested itself as a classical development state, it has revealed itself as an ambidextrous state (Peck 2010): "market-tolerant yet state-centric". In most sectors oligopoly is now a reality. Brazilian exports are dominated by Public-Private Partnerships with nationals and transnationals, such as Ceval in soy. Although homegrown agrobusinesses are growing rapidly, Brazil continues to be dominated by vertically integrating Transnational (agro-)Companies (TNCs) - the 'ABCD' (ADM, Bunge, Cargill, Dreyfuss) (Oliveira 2015). The four giants have a quasi-monopoly on soybean oil extraction, as well as a major stake in almost all the value chain, from seeds and pesticides to harbours and storage, and now Cargill is reportedly building a river transport fleet. ${ }^{7}$ These big guns have access to finance when cash is constrained and bring state-of-the-art technology while Brazil supplies the land, its resources, and labour.

Given Brazil's reliance on biofuels to substitute for imported fossil fuels (sugarcane-based ethanol but also soybased biodiesel) it merits mentioning that Brazil's energy sector is dominated by only six companies and a technocratic

\footnotetext{
${ }_{7}$ Cargill builds first waterway shipment fleet in Brazil. Wilson \& Sons. 12 February 2015. Online: Acceleracao http://www.wilsonsons.com.br/ agencia/en/press/news/cargill-builds-first-waterway-shipment-fleetbrazil
}

leadership, the economy as a whole by some 20 (Forbes 2014), and a concentration of money benefits of these 20 to invest billions in Brazil and outside Brazil, with six big corporations. A landmark in the public-private entanglement is the so-called 'PAC' or Plano de Accelaração de Crecimento (Growth Acceleration Plan) in which the big six partners in development of Brazil, form 'Strange cathedrals' (Campos 2014) such as mega-hydrodams and stadiums and infrastructure for the World Cup and the Olympics to social housing (the Minha Casa, Minha Vida programme).

The six, including Petrobras (energy), Vale do Rio Doce in mining (the second largest mining company in the world), and Odebrecht in engineering and construction, operate 'generally in tune with government foreign policy, as their own raison d'être is in great part due to their umbilical connection to the state that gives coverage to their monopolistic/oligopolistic situation' (Vieira 2011). This investment is heavily backed by Brazil's national investment bank, BNDES (Banco Nacional do Desenvolvimento Economico e Social) investing both in Brazil's backyard (Bolivia, Ecuador, etc.) as well as in Africa and backing up diplomatic overtures to the Middle East.

As so often happens in bullish claims of "win-win situations' there tend to be silent losers in the background too, often regarded by economists as 'externalities'. The externalities of cooperation in the present context are not trivial and this is the burden of the final section of this article.

\section{Geopolitics of Brazil-Middle East rapprochement}

The above has described BRICS not only as increasingly important trade partners supplying food needs in the Middle East, but also newly emerging donors, and Brazil has offered African development partner countries soft-power 'goodies' such as debt cancellation, embassies and scholarships. Yet despite the apparent benevolence, food can be a weapon, and Brazil's ventures abroad are not exclusively economic in 
nature. Sebastian and Warner (2014) have claimed that access to land, water or markets are unlikely to be the only consideration of the surging Foreign Direct Investment. Like everyone else, the BRICS seem to pursue geopolitical goals, such as spheres of influence. As noted, Brazil's Africa policy seeks to garner support for a seat at the United Nations Security Council, of which it has been a very long non-permanent member, by presenting itself as a rising Southern country, fundamentally different (i.e., neutral) in outlook from the industrialised North.

Latin America's total refocus on the primary sector (agriculture and mining) (re-primarization, Gudynas 2009) paradoxically only reinforces this trend. In this process, agricultural modernization plays a major part. Brazil has taken the lead in a global initiative against hunger, together with the World Food Programme (WFP), a move supported by France and others (Gratius 2007).

This agrodiplomatic activism (Juma 2011) is not a new phenomenon for Brazil. In the early 1970s, the prices of rice, wheat, maize, and soybeans skyrocketed. While the ruling dictatorship saw Brazilian overtures to Africa as tantamount to communism at the time, the oil crisis saw energy-hungry Brazil turn pro-Arab, including arms supplies (Global Voices 2012). Export of Brazilian defence technology took off in 1976 and until the late 1980s the Middle East was Brazil's biggest weapons market (Perlo-Freeman 2004; Inbar and Zilberfarb 1998).

Forty-plus years hence, more than $50 \%$ of Brazil's exports are not for the global North. Brazil's manifestation in the Middle East and elsewhere serves not only economic but clear political goals on both sides (Chatham House n.d.). Many Middle East states are 'rentier states' (Beblawi and Luciani 2012), buying legitimacy by redistributing wealth from external rents like oil sales and Suez Canal fees to the population. Ajl (2014) claims 'food security is a discourse which is mobilized in the [MENA] region and elsewhere for ends having little to do with securing food: namely, the distribution of state rents to social elites in ways which would otherwise be difficult to publicly justify'(Ajl 2014). For this, food should be plentifully available. Brazil and Sub-Sahara are considered areas in which land and water potential is plentiful. Let's go into the strategic history of this and subsequently arrive at the current nexus linking food, development and security.

\section{The green revolutions}

Duffield (2001) and others have long pointed at the development-security connection, in which economic development is subservient to geopolitical security interests-development for security. This was most visible in the post-World War II period, in which the spread of the Green Revolution served Cold War interests. Currently, it connects 'development for the hungry and security for the (privileged) rest of us' in one tidy package. This promoted the investment and spread of the Green Revolution, and in Brazil its own "second Green Revolution"' (Sommerville et al. 2014). The US envisaged a hub-and-spokes system of regional hegemons (policemen) and their wards from the 1970s Nixon Doctrine, which boiled down to delegating policing to cronies. ${ }^{8}$

When compared to other flatter South American states such as Argentina, Brazil has a challenging topography. While Brazil in recent decades has aggressively sought to expand the agricultural frontier through improving navigation channels, transport infrastructure is not Brazil's strongest suit. Yet the country has masterminded its own Green Revolution to work an agricultural miracle, first over the cerrado (savannah). The emblematic soy state is Mato Grosso, now the biggest producer in the world, next come Goias, Mato Grosso do Sul, Rio Grande do Sul and Paraná. The 'soy frontier' has moved from the South to the Centre-West of Brazil, accelerating the clearing of the cerrado (though not as much as for livestock); then increasingly spreading to the tropical Amazon rain forest, to put the pressure on deforestation there (Willaarts et al. 2011). Forest is often first cleared for cattle ranching, before being turned over to arable farming when the land is too exhausted (Domingues and Bermann 2012). A strong belief in efficiencies of scale sidelined and displaced 'small-scale' peasant operations. ${ }^{9}$ While low on fertiliser and rarely irrigated, herbicide use in Brazilian soy production is high (Fearnside 2001). As soy production is mainly export-oriented ( $73 \%$ in 2008), it means net virtual water export for food export, water allocations rising $23 \%$ between 2002 and 2008 (Willaarts et al. 2011). Finally, Fearnside (2001) argues soybean production has had knock-on effects, legitimising the construction of waterways, road and rail infrastructure, which in turn attracts mining and logging interests into the soy regions, including the Amazon.

A key figure in this drive was Blairo Maggi, CEO of the world's biggest soya company, André Maggi Group (Amaggi). When governor of Mato Grosso (2003-2010) and on Forbes' list of most influential people in the world, Maggi sought to double soy production. Amaggi has now turned its gaze onto the entire value chain, recently obtaining Rs 27 million (USD 6.5 million) in financial

\footnotetext{
${ }^{8}$ In the domain of current-day agrifood politics, this connection may invite a food mission creep. Economic development can be framed as anti-terrorism, even more so Post 9/11 (Prashad 2013).

${ }^{9}$ Although 'small-scale' is a relative term. A 300 ha operation counts as 'small' in Brazil, while it would rate as 'enormous' in the Netherlands, the author's present country of residence.
} 
support from Brazil's federal investment bank BNDES for the construction of grain silos to store soya and corn in the cerrado region. ${ }^{10}$ International funders likewise accelerated the expansion of soya, Bunge being one of the biggest promoters of rural investment (Otta 2014).

Given that soy was only a staple of Asian diets, and that Japanese migrants into Brazil have grown soy for over a century, the inexorable rise of soy in Brazil was not immediately obvious: 'Brazilian commercial farmers only began planting soybeans in any extensive manner after the 1940s as a cover crop and green manure to restore nitrogen to soils degraded by wheat production" (...) which was then "incorporated into the vegetable oil industry, with livestock feed as the constructed co-market. Only after soy became a consolidated industrial input for the vegetable oil and livestock feed markets, have soybean-processing companies in Brazil begun to promote its use as a human food, a food processing additive, and biodiesel" (Oliveira and Schneider 2014). Since the 1970s, however, Brazil has exploited its land and water riches domestically to part-convert its economy from fossil fuels to biofuels.

After the American soy-bean embargo and shortfall of Peruvian fish meal in the early 1970s, Japanese investors purchased land in Brazil for soy-bean production. Programmes such as Prodecer (Program of Brazilian and Japanese Cooperation for the Agricultural Development of the Brazilian Cerrado) promoted land concentration and foreign direct investment in Brazil (Clements and Fernandes 2012). While soybeans were customarily grown in the moderate climate zone, the Second Green Revolution enabled Brazil to colonise the tropical zones too. In so doing Brazil has not only become a major agro-food exporter, but also producer of biofuels, especially ethanol (import substitution) - sugarcane is grown traditionally in Sao Paulo but now also in the Northeast and Amazon (Stratfor 2012).

The Green Revolution in Brazil was Japan-assisted, and Japan has remained a big investor in Brazil; for example in 2007 Japan's Mitsui bought 100,000 ha in Brazil, while Brazil is partnering with Japanese in the enormous Prosavana project in Mozambique, spanning an area of 14 million ha of great biodiversity. This was chosen for its similar agro-ecology and climate to that of the Brazilian Cerrado and seeks to 'replicate' the experience of agricultural development there. The joint Nacala Fund, called after the central corridor in the project, was to furnish USD 2 billion to soybean businesses (Clements and Fernandes 2012). Prosavana, which runs from 2011 to 2016, is seen by critics as Brazilian land grab abroad (Avelhan 2013). An area the size of Switzerland and Austria

\footnotetext{
${ }^{10}$ Online: http://www.bndes.gov.br/SiteBNDES/bndes/bndes_pt/ Institucional/Sala_de_Imprensa/Noticias/2015/Agricultura/20150123_ graos.html
}

combined cannot only consist of 'abandoned areas' and indeed it is the most densely populated area in Mozambique (http://farmlandgrab.org/post/view/24367). Infrastructure in the project area, however, proved substandard, and hardly any Brazilian farmer took the opportunity to settle, causing a redrafting of the Master Plan (Fairhead et al. 2012).

The security-development nexus has found a new apolitical expression in the water-energy-food resource nexus, talk of which is especially prominent for the Middle East. The nexus explicitly puts resource interdependence in the security domain (Allouche et al. 2014) while at the same time holding out the promise of a resolution due to non-political benefitsharing between interdependent states. The reallocation of 'virtual water' from resource-rich to resource-poor countries, as key input for food and hydropower, would reduce the pinch of resource scarcity. The next Section goes into the realism of that assumption.

\section{Flush with cash, flush with resources? The downside of the Brazilian resource grab}

The intensive exploitation of one's own resources ${ }^{11}$ facilitates a kind of social peace (Swyngedouw 2007 on Spain, Warner 2012 on Turkey) by enlarging the 'cake' and providing employment. A focus on the primary sector induced by a 'resource curse' however has taken both its environmental and social toll as Brazil continues to draw down its resources at home and land grabs uproot thousands.

Sugarcane and soy are so-called flex crops: crops that can be used for food, feed, fuel or industrial materials. Grabbing land means direct access to food and energy, and may even be subsidised as 'climate investment'.

Currently the so-called Water-food-energy-climate Nexus is all the rage, with a view to promoting a Green Economy (Hoff et al. 2011; Allouche et al. 2014). The Nexus recasts environmental problems as the result of market failures rather than specific outcomes of marketisation (Corson et al. 2013). Environmental services, provided by water, benefit food and energy production and may allow benefit-sharing and mutual gains. Critics, however, have noted the green economy is tantamount to accumulation under a green banner. Political ecologists studying "ecological distribution conflicts" such as Guha and Martínez-Alier (1997: 31) and Adams (2004) have called attention to this 'ecological land grab' or 'green grab': direct foreign investment in mostly agricultural land for biofuels, climate buffers and green parks. Whether due to ecological land grab (conservationism) or green spaces

\footnotetext{
${ }^{11}$ An example of Brazilian 'internal colonization' facilitated by Dutch banks. The 'Plantar Project' in Minas Gerais, involving eucalyptus monoculture, financed by Dutch Rabo Bank, facilitates Green financing at lower interest rates and for income from the sale of $\mathrm{CO}_{2}$ reduction. Plantar sells these reductions to the PCF, of which the Rabo bank is a shareholder.
} 
sequestered for food or fuel, both serve to expel locals, often poor and/or indigenous groups and traditional black communities (quilombas). Hunters become poachers, squatters become bandits in a discourse seeking to preserve land for conservation. From this critical Marxist perspective the current fervour for 'land grabbing' may be seen as a new form of Primitive Accumulation with a benign, green face.

As noted, Brazil is flush with cash looking for investment. The country's foreign currency holdings jumped from USD50 billion to USD374 billion between 2006 and 2013 (Cascione 2013), though that figure may be inflated by the Central Bank's currency swaps, see Wheatley 2014: http://blogs.ft.com/beyond-brics/2014/01/15/brazilnet-debtor-to-the-world/). While this serves as a first line of defence against crisis, Corson et al. (2013) argue that '[as] over-accumulated capital seeks new investment opportunities, it discovers environmental protection as a new direct and speculative opportunity for investment through the production of mechanisms like carbon trading and wildlife derivatives'.

Brazil is commonly presented as having plenty of land and water to spare: according to the United Nations World Water Assessment Report of 2009, ${ }^{12}$ Brazil has the highest availability of renewable water per person in the world (some $43,028 \mathrm{~m}^{3} /$ capita/year). This water wealth has legitimised massive investment in hydropower plants, such as Belo Monte in the Amazon region. Brazil's 'resource curse' leads the country to invest massively in lusophone Africa to copy its agricultural achievements at home.

Many of the biggest and most aggressive foreign state investors are those facing real and potential arable land and water shortages at home: China, India, South Africa, Saudi Arabia, the United Arab Emirates, Egypt, South Korea and Japan. Brazil takes a twin role of investor and investee; the country remains one of the world's biggest targets for investment. "More than half of the foreign capital invested in land in Brazil comes from just seven countries: Portugal, Japan, Italy, Lebanon, Spain, Germany and the Netherlands' (Sauer and Leite 2012). In 2006, however, after a successful Greenpeace campaign (Greenpeace 2006), soy producers, authorities and concerned organizations negotiated a moratorium in which soy would not be grown any longer on deforested land in the Amazon. In 2007, moreover, President Lula considered limiting foreign land grabs in which $50 \%$ or more of the shareholdings were controlled by foreigners and set a maximum of one quarter foreign ownership of municipal areas. This plan was resisted by the opposition, preferring to give

\footnotetext{
$12 \mathrm{http} / /$ www.unesco.org/new/en/natural-sciences/environment/water/ wwap/wwdr/wwdr3-2009/

${ }^{13} \mathrm{http}: / /$ www.brazemb-ksa.org/commercial/134-agriculture-investmentfaqs 7 July 2013.
}

free rein to national companies even if they were foreignowned. 'The world is counting on Brazil to feed it!' Brazil continues to provide entrance - if with some limits ${ }^{13}$ - to massive foreign direct investment in the primary sector. Particularly, the states of Mato Grosso, Goiás, São Paulo, Minas Gerais, Mato Grosso do Sul and Bahia serve as the agricultural frontier, and as such the core 'land grabbing corridor' in Brazil' (Clements and Fernandes 2012).

However, the recipient state may not necessarily be better off in terms of resources than the investor. In the new virtual water geopolitics, water-poor countries not only invest in resource-rich countries, but also in countries with resource problems of their own. Saudi Arabia for example has invested in parched Egypt - the Toshka scheme in the desert (Warner 2013), while the Middle East is eyeing Brazil's land and water wealth.

In 2014-2015, Brazil experienced the worst drought in 60 years, and the impact of drought stress on domestic agriculture and industry is already being felt. While the intensity of the drought is unusual, it may have been self-inflicted by poor governance and water-guzzling production in ill-suited conditions. Due to a combination of serious mismanagement and some unusually dry seasons the country is seeing a serious water crisis in 2014-2015. Unlike energy (including hydropower), water is not subject to national policy in Brazil, so that there is no coordinated action on water management. The water managers of the state of Sao Paulo for example, a key agricultural producer, had no emergency planning whatsoever (Leite 2014), while the state's Governor Alckmin judged it convenient to ignore then downplay the dwindling resources until after the 2014 elections. By election time, however, almost 2000 Brazilian municipalities comprising over a fifth of the country's populace had declared a state of emergency over drought (Rodrigues 2014).

At a deeper level the ingrained culture of wastefulness, undervaluation of water resources and under-investment in water infrastructure improvement has a long history, especially but not exclusively during the military dictatorship (1964-1985) when 'development state' planners put a higher priority on economic development at the expense of growing environmental degradation and water scarcity (Victor et al. 2015). In its thrust for agricultural space Brazil has paid little attention to the fact that the Amazon river as well as the Pantanal wetlands are fed by Cerrado tributaries. The 'century drought' may have tipped a system over the edge that was already suffering from dismal governance and exploitation. The level in Brazil's hydroelectric dams has been dropping dramatically, so that hard choices needed to be made: whether to use surface water for energy or transport for agricultural exports. As a result, the Tiete-Parana waterway has been closed since May 2014, reducing soy transport. The alternative, haulage by lorry, was marred by a well-timed truck drivers' strike (BBC 2015). 
Lerrer (2015) argues that Cerrado rivers had already been sucked dry by soybean expansion before the crisis. Environmentalists such as The Nature Conservancy, World Wildlife Fund and Greenpeace saw the drought coming and formed the Alliance for Water (Aliança pela Água) in 2014 (Martin 2014). The alarm was unlikely to be heeded by a growthfocused government, whose new Science Minister, Rebelo, has declared the environmental movement is "nothing less, in its geopolitical essence, than the bridgehead of imperialism" (Watts 2015) and whose Agriculture Minister Katia Abreu unabashedly represents megafarms. Rather than address these root causes, the government's response to drought in Brazil has been to plan more hydropower dams (HEPP) in the Amazon to increase capacity (Carvalho 2012). This is in line with the nexus, which legitimises dams as 'green buffers' for water, food and climate security, but in fact, some claim, mainly serve nonsecurity goals, such as the financialisation of investor assets (Ahlers et al. 2015).

\section{Conclusion}

This article has examined vulnerabilities and strategies in the interdependent global food system. The threat of, say, a Brazilian export ban for geopolitical reasons seems unlikely. It is a scenario the EU's biggest soy importer, the Netherlands, has contemplated in light of the 2007-2008 food upheavals (Bindraban et al. 2009), and is certainly something importdependent countries such as the Gulf states worry about. The Middle East counts on Brazil (and Sub-Saharan Africa) to supply the food and minerals enabling its states to buy legitimacy without granting too much democracy. The current drought, however, put paid to the idea that the two regions are necessarily complementary in their resource abundance vs. resource poverty.

The concentration of the Brazilian agro-industrial complex would allow concerted action. There certainly is historic precedent of politically-induced volte-faces in food geopolitics (including the US in the 1970s (Harrigan 2014). Brazil threatening to embargo its exports would have a major impact, but the state does not seem motivated - to the contrary, it wants to sell. The current shortfall of Brazil's exports, then, is not due to any calculation, but the bizarre outcome of mismanaging plentiful resources and a politically motivated unwillingness to do any contingency planning. While seeking an outlet for its financial surpluses by investing heavily in African agricultural ventures, Brazil has been squandering its resource abundance at home, unintentionally causing potential interruptions in the soy economy due to the drought and subsequent closure of a key transport route. In so doing it has needlessly revived the spectre of global supply chain disruptions.

While Brazil does not seem intent on playing 'hard geopolitics', South-South cooperation is not as 'horizontal' and egalitarian as the word 'cooperation' might suggest. The country's 'soft power' aspirations on the global scene are buttressed by obvious domestic economic interests. Like the other BRICS, Brazil may "talk anti-imperialist" but wants a sizeable slice of the cake for itself (Bond 2013). And while the new middle powers may sound refreshingly low on ideology and paternalism, their moves are also depressingly low on sustainability. In promoting South-South cooperation, Brazil risks exporting a structurally exploitative model to other continents. Brazil's cosy domestic and foreign public-private 'concept of control' has its hazards. The major companies are also major campaign funders for Brazil's PT-led government, now in its fourth term. Current corruption cases against giants such as Petrobras and Odebrecht hit the Brazilian oligopolistic public-private complex hard, dampening bullishness about South-South cooperation, while the drought crisis has highlighted the deleterious effects of an exaggerated and destructive focus on primary sector monocultures, in so doing also shooting holes into the assumption that 'virtual-water exports' based on competitive agricultural specialisation are necessarily salutary outcomes of the water-energy-food nexus.

Acknowledgments This article has hugely benefited from inputs, feedback and support from Barbara Maisonnave Arisi at UNILA, Foz de Iguacu, Brazil, and from the comments of two anonymous reviewers. Responsibility for any error of fact or interpretation remains wholly mine.

Open Access This article is distributed under the terms of the Creative Commons Attribution 4.0 International License (http:// creativecommons.org/licenses/by/4.0/), which permits unrestricted use, distribution, and reproduction in any medium, provided you give appropriate credit to the original author(s) and the source, provide a link to the Creative Commons license, and indicate if changes were made.

\section{References}

Adams, W. M. (2004). Against extinction: the story of conservation. London: Earthscan.

Agbo, O. (2008). Nigeria-India relations under south-south cooperation. Nigerian Journal of International Affairs, 34(1), 32-51.

Ahlers, R., Budds, J., Joshi, D., Merme, V., \& Zwarteveen, M. (2015). Framing hydropower ass green energy. Assessing drivers, risks and tensions in the Esstern Himalayas. Earth System Dynamics, 6, 195204.

Ajl, M. (2014). Oil for food (book review). Journal of Peasant Studies, 41(4), 645-649.

Allan, J. A. (2001). Virtual water -economically invisible and politically silent- a way to solve strategic water problems. International Water and Irrigation, 21(4), 39-41.

Allouche, J., Middleton C., \& Gyawali D. (2014). Nexus Nirvana or Nexus Nullity? A dynamic approach to security and sustainability in the water-energy-food nexus Nexus article, STEPS, Sussex. STEPS Working Paper 63. University of Sussex.

Amanor, K. S. (2013). South-South cooperation in Africa: Historical, geopolitical and political economy dimensions of international development. IDS Bulletin, 44.4. http://onlinelibrary.wiley.com/ journal/10.1111/(ISSN)1759-5436/issues or http://opendocs.ids.ac. 
uk/opendocs/bitstream/handle/123456789/2612/IDSB44.4\% 20South-South $\% 20$ Cooperation $\% 20$ (April\%204).pdf?sequence=3.

Avelhan, L. L. (2013). A presença brasileira na África: um estudo sobre o Programa Embrapa-Moçambique. BSc thesis. Florianópolis, Federal University of Santa Catarina.

Bakker, K. (2007). Eau Canada. The future of canada's water. University of British Colombia Press.

BBC. (2015). Brazil lorry drivers' roadblocks 'affecting exports', BBC News, 25 February 2015.

Beblawi, H., \& Luciani, G. (2012). The renter state. London: Croom Helm.

Bindraban, P. S., Burger, C. P. J., Quist-Wessels, P. M. F., \& Werger C. R. (2009). Resilience of the European Food System to calamities. Report for the Steering Committee Technology Assessment of the Ministry for Agriculture, Nature and Food Quality, Plant Research International, Report 21. Wageningen, Wageningen UR.

Bleischwitz, R., Dozler, M. G., Johnson, C. (2012) Resource curse Redux Linking Food and Water Stress with Global Resource Supply Vulnerabilities. Transatlantic Academy Paper Series. May 2012. Online: http://www.transatlanticacademy.org/sites/default/files/ publications/Bleischwitz_Dozler_Johnson_ResourceCurseRedux_ May12_complete_web.pdf.

Boelens, R., \& Vos, J. (2012). The danger of naturalizing water policy concepts. Water productivity and efficiency discourses from field irrigation to virtual water trade. Journal of Agricultural Water Management, 108, 16-26.

Bond, P. (2013). Are BRICS 'sub-imperialists'? Pembazuka 20 March.

Burger, K., Warner, J., \& Derix, E. (2010a). Governance of the world food system and crisis prevention. http://www.stuurgroepta.nl/ rapporten/Foodshock-web.pdf. Accessed 1 October 2015.

Burger, K., Warner, J., \& Derix, E. (2010b). Governance of the world food system and crisis prevention. Platform agriculture, Innovation and Society/Ministry of Economic Affairs, Agriculture and Innovation www.platformlis.nl.

Campos, P. H. P. (2014). Estranhas Catedrais. as empreiteiras brasileiras e a ditadura civil-militar. Editora da UFF.

Carmody, P. (2011). The new scramble for Africa. London: Policy Press.

Carvalho, C. (2012). De 23 novas hidrelétricas planejadas na Amazônia, sete serão construídas em áreas intocadas. $O$ Globo. 3 September 2012. Online: http://oglobo.globo.com/economia/de-23-novashidreletricas-planejadas-na-amazonia-sete-serao-construidas-emareas-intocadas-6173007\#ixzz3TnAdXUAP.

Cascione, S. (2013). Brazil's foreign reserves are not all that big Reuters, 8 August. http://blogs.reuters.com/macroscope/2013/08/08/brazilsforeign-reserves-are-not-all-that-big/.

Cesarino, L. M. C. N. (2012). Anthropology of development and the challenge of South-South cooperation. Dossier "Anthropology, Cooperation and Development". Vibrant, Virtual Braz. Anthr., 9(1). Online: http://dx.doi.org/10.1590/s180-43412012000100017. http://www.scielo.br/scielo.php? pid=S 1809 43412012000100017\&script=sci_arttext.

Chatham House. Brazil in Africa: Just another BRICS country seeking resources. http://www.chathamhouse.org/sites/files/chathamhouse/ public/Research/Energy, \%2 0Environment\%2 0 and $\%$ 20Development/bp1113edibleoil.pdf.

Clements, E. A., \& Fernandes, B. M. (2012). Land grabbing, agribusiness and the peasantry in Brazil and Mozambique. Paper presented at the International Conference on Global Land Grabbing II October 1719, 2012. Organized by the Land Deals Politics Initiative (LDPI) and hosted by the Department of Development Sociology at Cornell University, Ithaca, NY.

Corson, C., MacDonald, K. I., Neimark B. (2013). Grabbing green markets. Environmental governance and the materialization of natural capital. Human Geography, 6(1), 1-15. (https://www.academia.edu/ 3152759/Corson C. MacDonald K.I. and B. Neimark 2013. Grabbing_Green_Markets_Environmental_Governance_and the
Materialization_of_Natural_Capital_Human_Geography_6_1_1$15)$.

Domingues, M. S., \& Bermann, C. (2012). O arco de desflorestamento na Amazônia: da pecuária à soja. Ambiente e Sociedade, 15(2), 1-22.

Duffield, M. (2001). Global governance and the new wars: The merging of development and security. London: Zed Books.

Fairhead, J., Leach, M., \& Scoones I. (2012). Green Grabbing: a new appropriation of nature? Journal of Peasant Studies, 39(2), 237261. doi:10.1080/03066150.2012.671770. Online: http://www. tandfonline.com/doi/pdf/10.1080/03066150.2012.671770

Fearnside, P. M. (2001). Soybean cultivation as a threat to the environment in Brazil. Environmental Conservation, 28, 23-38.

Forbes. (2014). The 20 companies that own Brazil. Forbes magazine, January.

Global Voices. (2012). Brazil Middle East economic policy under the radar. Global Voices Online. 7 July. Online: http:// globalvoicesonline.org/2012/07/17/brazil-middle-east-economicpolicy-under-the-radar/.

Gratius, S. (2007). Brazil in the Americas: A Regional Peace Broker? FRIDE Working paper 35.

Gray, J. (2014). Berlin Wall anniversary: 25 years of liberal delusion. Twenty-five years after the wall's collapse, the greatest threat to the west comes from the groundless faith that history is on its side. Prospect.

Greenpeace. (2006). Eating up the Amazon. Amsterdam: Greenpeace International.

Greider, W. (1997). One world, ready or not: The manic logic of global capitalism. New York: Simon and Schuster.

Gudynas, E. (2009). Diez tesis urgentes sobre el nuevo extractivismo. Contextos y demandas bajo el progresismo sudamericano actual. In: J. Schuldt et al. (Eds.), Extractivismo, política y sociedad (pp. 187-225). Quito.

Guha, R., \& Martinez-Alier, J. (1997). Varieties of environmentalism: Essays North and South. London: Earthscan.

Hanieh, A. (2011). Capitalism and class in the Gulf Arab States.

Harrigan, J. (2014). The political economy of Arab food sovereignty. London: Palgrave.

Harvey, D. (2009). The 'new' imperialism: Accumulation by dispossession.

HCSS. (2013). The emerging geopolitics of food. A strategic response to supply risks of critical imports for the Dutch agro-food sector. No 19 A report commissioned by Dutch Ministry of Economic Affairs. The Hague Centre for Strategic Studies.

Hoff, H., et al. (2011). Understanding the nexus. Background paper for the Bonn 2011 conference: The water, energy and food security nexus. Stockholm: Stockholm Environment Institute.

Inbar, E., \& Zilberfarb, B. (1998). The politics and economics of defence industries (BESA Studies in International Security). Abingdon: Routledge.

Jafri, A. (2008). Food crisis exposes failings of India's economic reforms. Focus on Trade, No. 140, May. Bangkok: Focus on the Global South. http://focusweb.org/focus-on-trade-number-140-may-2008. html?Itemid $=106$.

Juma, C. (2011). Seeding diplomacy. Public Service Review.

Kelman, I. (2006). Acting on disaster diplomacy. Journal of International Affairs, 59(2).

Koning, N., \& Mol, A. (2009). Wanted: institutions for balancing global food and energy markets. Food Security, 1(3), 291-303.

Kuntz, R. (2014). O novo capitalismo do Estado - e do PT. O Estado do Sao Paulo. Online: http://opiniao.estadao.com.br/noticias/geral,onovo-capitalismo-de-estado-e-o-do-pt-imp-, 1531081.

Lassance, A. (2012). Coluna: Capitalism de Estado e o Carruto de Lenin. Carta Capital, 21. http://cartamaior.com.br/?/Coluna/Capitalismode-Estado-e-o-charuto-de-Lenin/.

Leite, F. (2014). Bacias hidrográficas de SP não têm plano de emergência contra falta d'água. O Estado do Sao Paulo. 
Lerrer, D. (2015). A Lógica Pau-Brasil. Blogpost on 'Fazendo Correr o Risco', 17 February 2015. http://fazendocorrerorisco.blogspot.com. br/2015/02/a-logica-pau-brasil.html. Last accessed 10 October 2015.

Marini, R. M. (1972). Brazilian Subimperialism. Monthly Review, 23(9).

Martin, M. (2014). A eleição serviu de desculpa para não tomar medidas contra a crise hídrica. El Pais. Online: http://brasil.elpais.com/brasil/ 2014/11/07/politica/1415395509_180071.html.

McGinley, S. (2012). Saudi to invest $11 \mathrm{bn}$ in farmland projects. Business, com. 20 September. Online http://www.arabianbusiness.com/saudiinvest-over-us-11 bn-in-farmland-projects-473653.html.

McMichael, P. (2009). The food crisis in historical perspective, monthly review, July-August. Online: http://www.globalresearch.ca/index. php?context=va\&aid $=14378$.

Nogueira, I., \& Ollinaho, O. (2013). From rhetoric to practice in SouthSouth development cooperation: A case study of Brazilian interventions in the Nacala corridor development program. Working Paper. Institute of Socioeconomics University of Geneva. Online: http:// unige.ch/sciences-societe/socioeco/files/1114/0723/5655/ NOGUEIRA_OLLINAHO_WorkingPaper_NACALA_ CORRIDOR.pdf.

Nye, J. S. (1990). Born to lead. The changing nature of American power. New York: Basic Books.

Oliveira, G. L. T. (2015). Chinese and other foreign investments in the Brazilian soybean complex. BRICS Initiative for Critical Agrarian Studies (BICAS). Working Paper no. 9.

Oliveira, G. L.T., \& Schneider M. (2014). The politics of flexing soybeans in China and Brazil. Think piece series on flex crops \& commodities No. 3. Transnational Institute (TNI) Agrarian Justice Program.

Otta, L. A. (2014). Gigantes do agronegocio se unem para investor nas novas ferrovias. Estado de S.Paulo. 23 March.

PBL. (2011). "Scarcity in a sea of plenty?" Global Resource Scarcities and Policies in the European Union and the Netherlands. The Hague: Planbureau voor de Leefomgeving (Netherlands Environmental Assessment Agency).

Peck, J. (2010). Zombie Neoliberalism and the Ambidextrous State. Theoretical Criminology, 14(1), 104-110.

Perlo-Freeman, S. (2004). Offsets and the development of the Brazilian arms industry. In J. Brauer \& J. P. Dunne (Eds.), Arms trade and economic development theory, policy, and cases in arms trade offsets (pp. 185-201). London: Routledge.

Prashad, V. (2013). Neoliberalism with Southern characteristics. The rise of the BRICS. Rosa Luxemburg Stiftung, New York Office. Online: http://www.rosalux-nyc.org/wp-content/files_mf/prashad_brics.pdf.

Rodrigues, A. (2014). Ministério reconhece estado de emergência em sete cidades atingidas por chuvas ou seca. Hoje Sao Paulo. 23 October. Online: http://hojesaopaulo.com.br/noticia/ministerio-reconheceestado-de-emergencia-em-sete-cidades-atingidas-por-chuvas-ouseca/7918.

Sadik, U. (2013). BRICS- reality or mirage?: BRICS and the making of multipolarity in the global political economy. Insight Turkey, 15(3), 77-94. Online: http://file.insightturkey.com/Files/Pdf/15_03_2013_ unay.pdf.

Sauer, S., \& Leite, S. P. (2012). Agrarian structure, foreign investment in land, and land prices in Brazil. Journal of Peasant Studies, 39(3-4), 873-898.

Sebastian, A. G., \& Warner, J. F. (2014). Geopolitical drivers of foreign investment in African land and water resources. African Identities, $12,8-25$.

Sommerville, M., Essex, J., \& Le Billon, P. (2014). The 'global food crisis' and the geopolitics of food security. Geopolitics, 19(2), 239-265.
Stratfor. (2012). The geopolitics of Brazil: An emergent power's struggle with geography. Stratfor Global Intelligence. Online: https://www. stratfor.com/analysis/geopolitics-brazil-emergent-powers-strugglegeography.

Victor, D., Almeida, R., \& Wong, L. (2015) Water management policy in Brazil. Working Paper. Laboratory on International Law and Regulation, University of California, San Diego.

Vieira, M. B. (2011). The semi-periphery in Africa. The case of Brazil. Paper presented during the African Studies conference 'African Engagements: On Whose Terms?' Uppsala, 15-18 June 2011. Nordiska Inst.

Wallerstein, I. (1974). The modern world system: Capitalist agriculture and the origins of the European world economy in the sixteenth century. New York: Academic.

Warner, J. (2012). The struggle over Turkey's Ilisu Dam: domestic and international security linkages. International Environmental Agreements, 12(3).

Warner, J. (2013). The Toshka mirage in the Egyptian desert-river diversion as political diversion. Environmental Science and Policy, 30, $1-11$.

Watts, J. (2015). Brazil's worst drought in history prompts protests and blackouts 23 January. Online: http://www.theguardian.com/world/ 2015/jan/23/brazil-worst-drought-history.

Wheatley, J. (2014). Brazil: net debtor to the world. Financial Times, 15 January Online: http://blogs.ft.com/beyond-brics/2014/01/15/brazilnet-debtor-to-the-world.

Willaarts, B., Niemeyer, I., \& Garrido, A. (2011). Land and water requirements for soybean cultivation in Brazil: Environmental Consequences of food production and trade, XIVth World Water Congress. Brasil: Porto de Galinhas.

Woertz, E. (2011). Arab food, water and the big Landgrab that wasn't. The Brown Journal of World Affairs, 18(1). http://www.brown.edu/ initiatives/journal-world-affairs/181/arab-food-water-and-biglandgrab-wasnt.

Woertz, E. (2013). Oil for food. The global food crisis and the Middle East. Oxford: Oxford University Press.

Zibechi, R. (2014). The New Brazil: Regional integration and the new democracy. Oakland: AK Press.

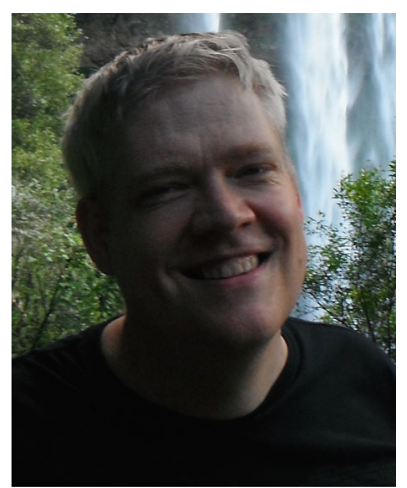

Dr Jeroen Warner is Associate Professor of Disaster Studies at Wageningen University and is a CAPES-funded Special Visiting Professor at the University of Sao Paulo, Brazil. He is particularly interested in the water-food nexus, and has given training on Integrated Water Resource Management in Ecuador, Bolivia and the Netherlands. He coordinates a European 'Horizon 2020' network on disaster, culture and social networks (EDUCEN), is a co-editor of the International Journal of Water Governance and editor of Ambiente e Sociedade. A founder member of the London Water Research Group, he also sits on the Netherlands UNESCO Water Commission. He has published over 80 peer-reviewed articles and seven books, plus professional publications on water, food and disaster. 